\title{
Reflecting on Contemporary India's Rising Inequality: Does Differential Rate of Return to Education Matter?
}

\author{
Sudip Chakraborty ${ }^{1,2, *}$ \\ ${ }^{1}$ Human Rights Centre, Law School as Fulbright Visiting Lecturer in 2008, University of Minnesota, USA \\ ${ }^{2}$ Department of Economics, Ananda Chandra College, Jalpaiguri, West Bengal 735101, India
}

Copyright $\bigcirc 2018$ by authors, all rights reserved. Authors agree that this article remains permanently open access under the terms of the Creative Commons Attribution License 4.0 International License

\begin{abstract}
Abstract India's rising income inequality to large extent is caused by the enormous difference in learning outcomes after completion of education. Decomposition analysis of India's current state of inequality points out that rural income inequality causes this outcome. The interstate difference in mean income and the urban-rural gap of mean income within states are often held responsible for giving rise to India's current state of income inequality. Intra-state income inequality is no less responsible. Non-farm sector has been expanding rapidly and within that category service sector is expanding. Service sector works need skills in various trades. Thus, unskilled and semi-skilled workers are left out in this new pattern. Formal employment is also characterized by duel wage structure. Income disparity or earning differential has its roots embedded in education delivery system in particular and human capital formation in general. The state must create opportunities for growth for all through provisioning of universal quality education and healthcare.
\end{abstract}

Keywords Inclusive Growth, Non-farm Sector, Dual Wage Structure, Wealth Inequality

\section{Introduction}

India is on course to join the league of high unequal nations of the contemporary world where she would be a partner accompanied by Brazil, South Africa and Argentina. This appalling aspect of the 'emerging' India was brought to light in 2006 by a research undertaken jointly by National Council of Applied Economic Research (NACAER) and the University of Maryland of the United States. India is now more unequal nation than China. India's income Gini of 0.53 is higher than China's income Gini of 0.47. China is less unequal than India despite her economic growth faster than that of India and per capita GDP of China is almost three times higher than that of India. According to the World Bank, per capita GDP in 2005 constant US dollar was 3,348 for China and the same was 1,107 for India. Strikingly, India's current inequality is significantly driven by rising consumption inequality in rural areas. Poverty mapping exercise undertaken to locate the relative concentration of poverty in various regions of India has revealed that rural income inequality is already on level pegging with urban inequality. India's rural society usually has been more egalitarian than her urban counterpart. But this feature of India is on way to become the past one. In some of the states in India, in Andhra Pradesh, for example, rural areas are more unequal than urban areas (World Bank 2011).

Mounting economic inequality in India evidently derails India's cherished goal of inclusive growth as laid down in the broad objectives of the successive five year plans. Increasing economic inequality does not augur well for India's rural society which is still afflicted by widespread caste-based and gender-based discrimination. Economic disparity would further strengthen the social disparity that undermines the spirit of shared citizenship for India hailed as the largest democracy in the world. Persistent inequality in rural India paves the way for concentration of economic power in few hands. This skewed distribution of economic power is pregnant with two unwelcome possibilities. One is the proclivity among the rural neo rich to get way with the larger share of the pie of government benefits meant for the rural areas. Money power begets muscle power. Pocketing of government benefits by sheer power and influence would widen the existing gap between the haves and have-nots. The other adverse impacts relate to fair polity and democracy. Affluent rural section tends to dominate the local power structure. Economic power and vested interest can wreck the political participation of the underdogs. The destitute can lose the freedom of choice in regard to electoral decision. Powerful few can influence the voting behaviour of the powerless through intimidation. Hegemony of the few in rural India deepens and perpetuates poverty. This asymmetrical economic condition in India's rural landscape bears the seed for social disharmony, popular dissent and disruption. The makers of modern India who had envisioned an egalitarian India had adopted planned development course for the newly born free nation. Economic empowerment of the 
underprivileged through programme and actions was set as priority agenda during the beginning of our planned development.

\section{How Did India Become Unequal over the Years?}

The period following the birth of India as a free nation was marked by significant economic inequality. Urban rural divide was prominent in the regional dimension of India's economic inequality. During 1950, urban inequality, as measured by Gini index, was close to 40 per cent and rural inequality was 35 per cent. Inequality, however, began to fall later for both urban and rural areas. Both fell together almost at the same pace up to late seventies. Thereafter, from 1980, they diverged. Urban inequality went up and was still on the rise while rural inequality was on falling spree up to the end of the last millennium and on little rise thereafter (Ravillion and Dutt 2009 [6]). The urban income inequality has been on the rise after $80 \mathrm{~s}$. The same is on faster rise during the period from 1990 to 2000. Urban inequality declined in India until 1980 and thereafter it started rising. The interesting revelation is that rural growth tended to be pro-poor during the period from 1983 to 1993-1994. Thereafter, the growth ceased to become rural-biased. It turned out to be neutral during the period from 1999-94 to 2004-05. While rural economic growth remained neutral during this period, urban economic growth favoured the urban rich (Ravillion and Dutt 2009 [6])

Thus overall economic inequality came down during the period from 1983 to 1993-94. But it rose slightly after that. Comparatively slower rise in economic inequality in last decades, as presented in the official release is contradicted by a section of development economists led mainly by the opponents of neoliberal economic policies adopted in India since 1991. They point out that household consumption survey do not capture the huge income of the neo-rich class in the Indian society swelled by the neoliberal policy of the government. They invoke the issue of under-reporting. The rank of the affluent people has been growing at a speed, the parallel of which is missing not only in the past. Ostensible penury persists side by side with visible affluence in India's expanding urban locations. One study in 1999-2000 reveals that the gap in per capita income between the $99^{\text {th }}$ and $99.5^{\text {th }}$ percentile was almost four times as large as the gap between the median person and the $95^{\text {th }}$ percentile. Income of the super-rich at the $99.99^{\text {th }}$ percentile grew by over 285 per cent between 1987-88 and 1999-2000 (Banerjee and Pitketty 2003 [1]). Wealth inequalities have been going up for fast in contemporary India. Wealth holdings of Indian billionaires are estimated to have gone up from 0.8 per cent of GDP in 1996 to 23 per cent of GDP in 2008 (Walton 2010 [15]). The growing urban-rural gap in mean income is identified by some as main trigger in causing overall income inequality in India. Inter- state difference in mean income is also held responsible for generating income inequality. The disparity in mean income as measured by real per capita NSDP among India's constituent states has been widening over the years. Measured by Standard Deviation (SD) technique, the disparity in mean income was relatively low in 1970 at 0.12 SD. But it exceeded 0.20 in 2006. Rich states have average incomes four times of that in poor states. But an inter-state difference in mean income does not constitute itself to be the only trigger of India's current economic inequality. However, decomposition analysis on inequality (World Bank 2011) reveals that intra-state inequality is the dominant driver of inequality.

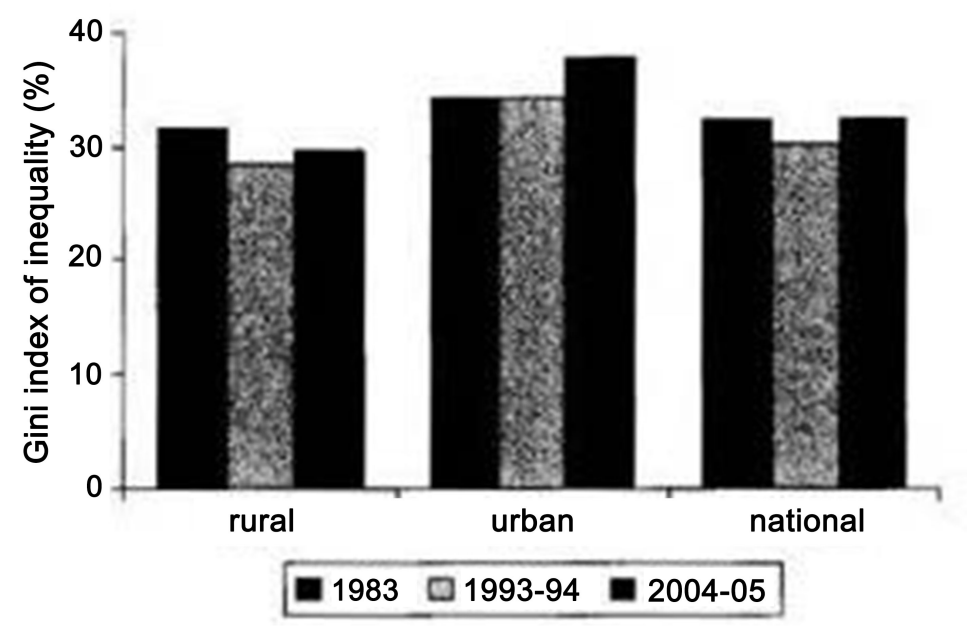

Source: Authors' estimates from respective NSS rounds.

Note: Gini index of uniform recall-period consumption corrected for cost-of-living differences across states using poverty line deflators. 


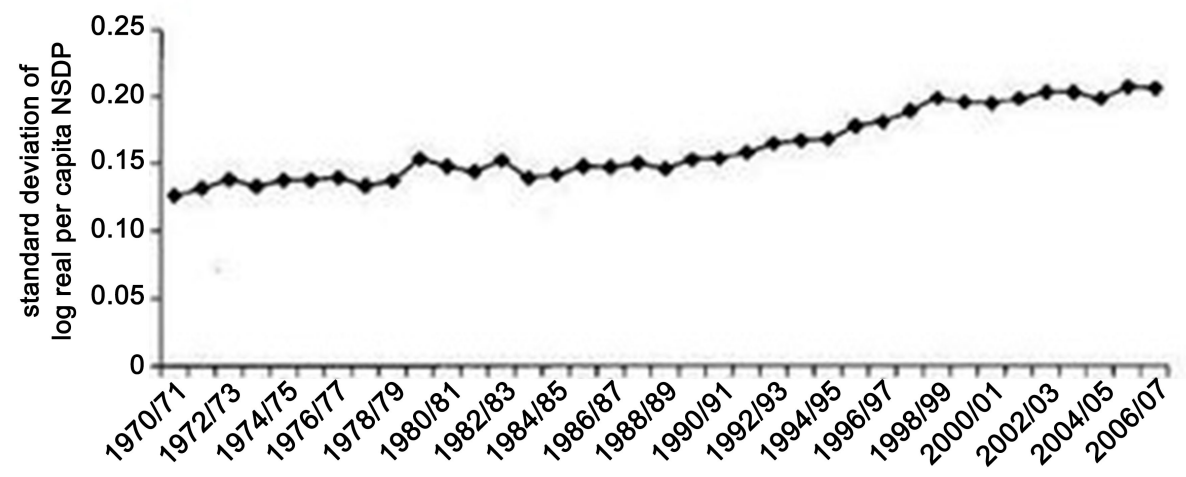

Source:Walton 2008.

Note: Based on data from 23 Indian states

Visited http://www-wds.worldbank.org

Figure 2. Spatial Differences Have Grown

The national account data as presented in the figure 2 points out the growing inter-state inequalities in mean income. During the 70s well before the onset of neo-liberal economic regime rich states used to have average income twice those of poor state, now the ratio is almost four times. However, a decomposition analysis using survey data reveals that only a small share of overall consumption inequality can be attributed to interstate or between-state differences in mean income. It came to light that inequality of consumption within the state and within regions is more powerful. Thus income inequality is substantially generated by the location of habitation or region of residences. A person residing in the prosperous region within a state is likely to earn much more than her counterpart hailing from a remote and backward region of the same state. This happens despite having same qualification and ability for both of them. Employment opportunity is extremely limited in the backward region, isolated from the urban centre or physically separated because of its unusual situation in hills or around the forests. These difficult regions are marked by dependence on mono cropping agriculture as the source of livelihood.

\section{Growth of Nonfarm Sector and the Demand for skill}

Education is expected to equip the learners with skills. The process of learning that equips the learners with skills appropriate for gainful employment has been bypassing a large section of youths in India. Unskilled and semiskilled workers can take up farm activities particularly in wage employment. But non-farm activities need skilled workers. Non-farm sector has been expanding in rural India. This is clear departure from the usual feature of rural growth in India. We are used to the wisdom that farm growth is synonymous with rural growth. India's non-farm sector provides job to 30 per cent in 2004. More than twenty years ago, in 1994, it provided job to 20 per cent job to rural workers. During the last decade of the last century nonfarm employment grew four times faster that farm sector (Sundaram, K 2007 [14]). Strikingly more than two thirds of the new jobs created in the non-farm sector falls within service sector. The latter require some skills in various trades. The share of casual employment in total nonfarm employment has gone up from 24 per cent in 1983 to 29 per cent in 2004. Dual wage structure has been emerging in the formal employment: well-paid high end and middle level employees have witnessed a significant rise in the average wage. But poorly paid regular employee at low end has witnessed very little growth in average wage although their number had grown. The trend towards casualization of the nonfarm sector is evident. This gives rise to income inequality in India. 
a. Rural

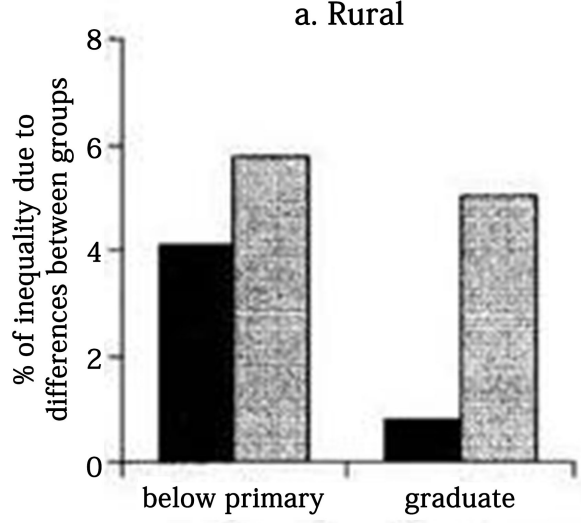

b. Urban

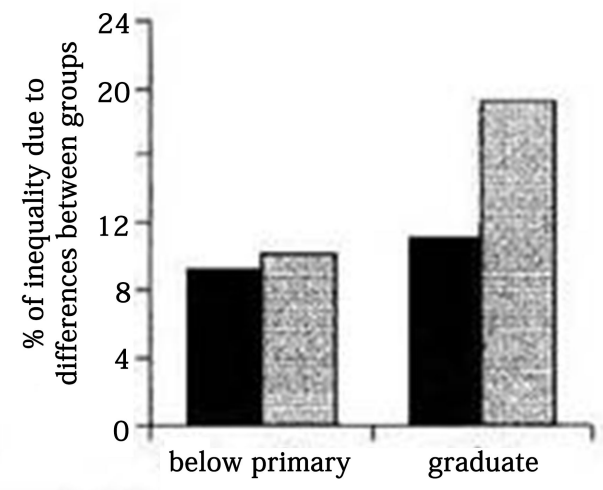

1983 ⑳04-05

Source: Authors' estimates from respective NSS rounds.

Note: Peroentage of inequality due to difference between given education category compared with the rest of the population.

Visited http://www-wds.worldbank.org

Figure 3. Increased Returns to Education are driving are driving rising inequality.

\section{Earnings Inequality and Differential Rate of Return to Education}

The other factor that contributes to economic inequality is the differential return to education of the earners. Wage differential is quite high between skilled and unskilled workers. Skill is acquired through educational process that starts from primary education as the foundation. A full course primary education of children equips them with basic skill in reading, writing and numerical calculation. The primary education is not only the gate way to secondary and post-secondary higher learning; it also trains the learners with some rudimentary problem solving skills in everyday lives. An unlettered worker is prone to exploitation by her employers. She is likely to be duped by the unscrupulous employers as

(S)he cannot read and understand work conditions and payment schedule. Her entry to the literate world is almost stopped by his lack of literacy skill. Primary education dose not land one to any high paid jobs in the business or service sector but it still make a difference in lower end job. Completion of quality primary education of eight years can make a difference in productivity and earnings in agricultural occupation. Unlettered small peasants fail to read the instruction printed in the box containing pesticides or inorganic fertilizers. Those written lines give the instruction for proper dose for single use or for blending to achieve best result in the field. Peasants having a full course of primary education stand ahead of those who do not have. Income earning capacity is correlated with educational attainments. Decomposition analysis conducted to locate the factors giving birth to inequality points out that the influence of primary education on urban income inequality is present but very insignificant. But graduate education makes a large difference. The share of income inequality explained by graduate education went up from only 11 percent in 1983 to 20 per cent in 2004-2005 (Figure 3). The increasing return to education for workers in India is the testimony of the assertion that nonfarm economic activities are overtaking agriculture in India. Nonfarm activities require skill in diversified fields where as farm sector can manage with very little rudimentary skill. Education would be needed as the countryside of India shifts from agriculture to nonagriculture activities. Even primary education completers can escape low paying agriculture. It is not hard to understand that the differences in income are caused by differences in educational attainments.

Access to education, particularly to elementary education has expanded spectacularly. The expansion began from $2^{\text {nd }}$ half of the $90^{\mathrm{s}}$ under the auspices of the DPEP. Sarva Shiksha Mission followed by Right to Free and Compulsory Education came in the new millennium. Access to elementary education in India is near universal for the children. But what is far from universal is quality learning. Unfortunately inequalities in learning achievement are high in India. Rewards to skill are becoming more unequal (Dutta 2006 [7], Kijima 2006 [9]).In rural India changes in educational attainments had strong inequality-increasing effect (Pieters 2011 [8]). Pieters identifies pervasive illiteracy in rural India as a causal factor. The interesting revelation of his study is the role of women's education which is characterized by exclusivity. Only educated women in rural India tend to beget smaller number of children. Thus education has been found to work through fertility reduction. He finds that increase in women's education and resultant decline in the number of children was much smaller in poor households. 
Uneven increase in educational attainment contributes directly as well as indirectly to higher rural inequality (Pieters 2011 [8]). Distribution-neutral increase in average educational attainment can increase inequality. Rising educational attainment increased household inequality because the inequality of education itself increased (Bourguignon, et al, 2005 [5])

\section{Schooling: Quantity, Quality and Skill Differential}

Schooling participation, as captured statistically by the rate of enrolment and retention, has significantly improved in contemporary India. Children are attending schools in large magnitude now. Early childhood (3 to 5 years of age) school attendance has increased quite substantially during the period under study. Using National Sample Survey data for the period from 1993 to 2004; clubbing all age groups (5-29 years), the attendance ratio for rural children has jumped from 37.9 percent to 53 percent for boys and girls together.
Elementary school attendance has been quite impressive. Almost 80 percent of rural girls are attending school in 2006, up from less than 60 percent during early $90^{\mathrm{s}}$. An ideal scenario in school education is judged by age appropriate grade enrolment. Presence of over-aged in each grade of schooling is an unhealthy symptom. But the situation has greatly improved by this time. The magnitude of overage students is on the wane. The gender gap in school attendance has also come down. The surge in attendance has occurred in poor households in educationally backward states. The gender gap and urban rural divide in primary school attendance have been substantially bridged. But the gap in higher grade is bridging at a slower pace. Literacy percentages among Indians have been on the rise since 1951. It was 21.82 per cent in 1951 but it has gone up to 79.31 per cent in 2011. This will further go up in the coming days as positive outcome of increased school attendance in recent years. India's generational mobility in educational attainments across social groups and wealth categories has also increased. Educational participations are higher now in the present generation than the earlier generations for the same family.

Table 1. Attendance Increased substantially in the Past Decade, Particularly in Elementary School

\begin{tabular}{|c|c|c|c|c|c|c|c|c|}
\hline \multicolumn{5}{|c|}{$1993 / 94$} & \multicolumn{4}{|c|}{$2004 / 05$} \\
\hline \multicolumn{3}{|c|}{ Rural } & \multicolumn{2}{|c|}{ Urban } & \multicolumn{2}{|c|}{ Rural } & \multicolumn{2}{|c|}{ Urban } \\
\hline Age Group & Male & female & male & female & Male & female & male & female \\
\hline Age-5-29 years & 45.4 & 30.5 & 47.7 & 34.9 & 53.2 & 43.6 & 54.1 & 51.9 \\
\hline Age- $3-5$ years & 17.2 & 15.0 & 35.5 & 32.3 & 30.6 & 29.0 & 49.0 & 47.9 \\
\hline Age-6-14 years & 74.5 & 58.2 & 87.0 & 82.4 & 86.9 & 79.5 & 91.0 & 89.5 \\
\hline Age-6-10 years & 74.0 & 60.4 & 87.5 & 83.8 & 87.6 & 83.2 & 88.7 & 85.0 \\
\hline Age-11-14 years & 75.3 & 54.5 & 86.4 & 80.6 & 85.8 & 74.1 & 88.4 & 86.9 \\
\hline Age- $15-18$ years & 43.0 & 22.3 & 59.1 & 52.0 & 49.4 & 36.0 & 61.0 & 59.3 \\
\hline Age-19-29 years & 8.0 & 2.4 & 16.8 & 9.9 & 8.6 & 3.9 & 17.4 & 12.3 \\
\hline
\end{tabular}

Source: Author's estimate based on NSS data (http://www-wds.worldbank.org)

Note: table reports percentage of age group currently attending school 


\section{Quantitative Expansion does not match with Quality Attainment}

Does this quantitative expansion in school attendance and enrolment across length and breadth of India commensurate with learning achievement? The issue is not only pertinent. This has a significant implication for country's development prospects. This is not a healthy picture that little children are crowding the school but finishing schools without learning anything or with a little learning at the end. Four to five years of primary schooling should equip the learners with three Rs: reading, writing and arithmetic. These basic skills are imparted to the younger children during the primary level of learning. Unfortunately, learning attainment for children might be cause of worry for our planner of education. The concern is aired that quality is running far behind quantity. Research studies by different organizations, both at centre as well as at state levels are being undertaken since mid- $90^{\mathrm{s}}$ to assess the learning attainment of students. One such study was taken up by the National Council of Educational Research and Training (NCERT) in 2009 [12]. The study was named as National Midterm Achievement Survey. The target group was class five students. The study reported that average score was 48 per cent in mathematics and 60 per cent in language. Annual Survey of Education Report, ASER in short, is being published by PRATHAM [11] regularly. PRATHAM is an NGO of wider repute, engaged in assessing quality attainment of primary school-going children in the entire country. Academic competency is measured in relation to the syllabus designed for each grade of primary education. They measure the gap between what a child actually knows and what she needs to know as per her age in a given grade. Pratham's reports are widely accepted by academicians and scholars as authentic references in discourse on quality and quantity of primary education in India.

The organization's report for 2010 can be taken up to make an idea about the state of quality in primary educations. One shocking revelation is that 9 per cent of children in grade 5 could not identify numbers up to 100 .
Grade 5 students are supposed to read a very short paragraph. The shocking revelation is that 44 per cent could not read a short paragraph of grade 2. It was also found that 29 per cent were unable to divide and subtract. The assessment was undertaken on the children reaching almost the end of primary education of five years. Out of three Rs: two Rs: Reading ability and Arithmetic competency were taken up for testing among them. After 5 years of primary schooling, 7 per cent of them can only recognize letters, no words and no sentences. Among these children, 13 per cent could read the words and 25 per cent could read text meant for grade 1. Learning attainments are not only below the ideal mark but also highly unequal among the young learners. Quality of learning varies across states in India. The other dimension of quality is intra-state variation (NCERT 2009 [12] Pandey, Goyal and Sundaraman 2008 [10]). Children in remote villages in any state in India having schooling facilities much below the mark are less likely to learn that meets the standard set of assessment of academic competency. School facilities incorporate adequate teachers, text books, attendance, teacher-pupil ratio, school buildings and class rooms, teaching aids, teachers' training as well as playground for stimulating body and mind of little learners. Facilities for schooling are not distributed squarely across the state despite the introduction of Operation Black Board, DPEP in the 90s and Sarva Sikksha Aviyan in recent years. Attempts are being made to bring about uniformity in schooling infrastructure. But the skewed structure in the distribution of facility built over more than six decades cannot be dismantled overnight. But the drive must go on. Variation in quality attainment across school can be attributed to differences in school facilities. Family background does matter in learning attainment of children. Education of parents, particularly of mothers, can greatly influence learning attainments of their offspring at school. Unlettered parents are always at the receiving ends because of their inability to teach and guide at home. Parental illiteracy and household poverty are two sides of the same coin. 
a. Reading: \% children in grade $\mathrm{V}$ with the skill

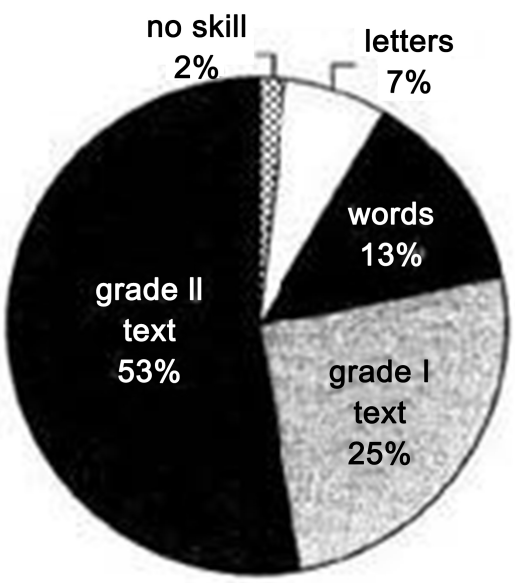

b. Arithmetic: \% children in grade $\mathrm{V}$ with the skill

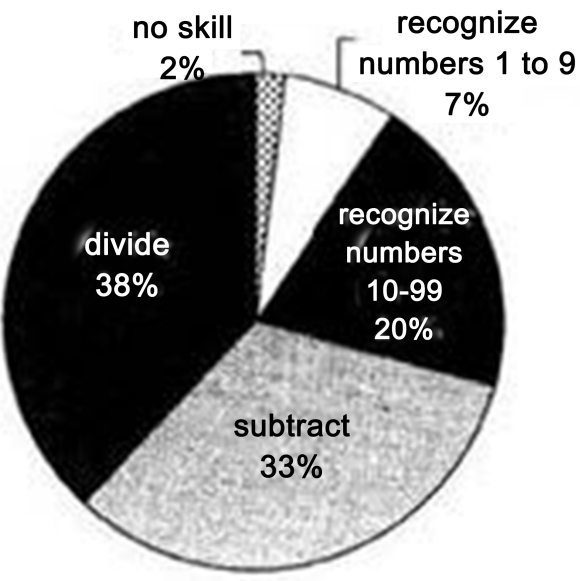

Source: Pratham 2010.

Note: The panels are to be interpreted as follows: 7 percent of children in grade $\mathrm{V}$ can only recognize letters, 13 percent can recognize both letters and words, and so on.

Visited http://www-wds.worldbank.org

Figure 4. Children Learn Little Even after Spending 5 Years

\section{Barriers to Quality Learning}

Social stratification reinforced by economic deprivations can also influences educational outcome. For example, children belonging to tribal communities are always at disadvantageous position vis-à-vis the general caste or other social categories (Burra N 2008). The weak standing of tribal children is generated by their lack of grip over the state language in which teaching learning is transacted in class rooms at government schools. Obviously, these children are uncomfortable with the state's dominant language which they do not speak at home. Learning outcomes are also influenced by economic power of the families to which the children belong. Deficiency of learning at schools can be compensated by supplementary coaching at home. Ability to provide coaching by the parents therefore, is also an influencing factor. Pratichi study report prepared by Pratichi Trust instituted by Noble Laureate Amartya Sen [13] has brought to light the widespread deficiencies in learning achievement at the primary schools in the selected villages in West Bengal. The study founds the prevalence of private coaching among the underprivileged families in the study villages. The astonishing and painful revelation is that families living from hand to mouth have been keeping aside a part of meagre income for private tuition. Poor parents are coughing up their hard earned incomes for the sake of their children's education. Poor parents are spending on such items for which the state is obligated to provide free of cost as per the Constitution. The Nation is looking forward to Right to education act that came in to effect in our country on and from $1^{\text {st }}$ April, 2010.

\section{The Passage to Productive Adulthoods and Public Investment for Children}

Human Development for the poor is posing serious challenges to the growing India. The contemporary growth performance of the Indian economy has earned appreciation worldwide. India's conventional image as a caste-ridden over-populated poor nation in the south Asia is fast fading. Her new image in the new millennium as a growing economic power is being built up. Her new image is made by her thriving service sector. India is now world leader in information technology services particular in developing software for the developed countries. But the economic growth should not be the final end of any nation. This is just means to achieve well-being of people (Sen, 1999 [13]. It just provides the opportunity for the state to make use of the increased income for enhancing capability of people. Income as such has no value unless it is translated in to good life. But sustainability of the growth depends on human capital formation process which should be the priority of the government action. Child malnutrition is such an issue at the moment in India which must receive priority attention. The child with stunted growth is almost sure to become unproductive adult in her turn. Undernourished and sickly children of today are on their way to become incompetent adults in future. The country needs skilled, healthy and intelligent youths in the coming days to sustain the growth momentum. Economic opportunities being created by the ongoing growth are being pocketed by privileged class in Indian society. Fruits of growth in the contemporary India are not being shared 
by all sections of Indian society. The underdogs are manifestly bypassed. These deprived lots include unlettered, unskilled, perennially ill, terminally sick, socially marginalized, tribal communities, indigenous and ethnic people and so on. The unskilled adults are those who missed quality schooling in their childhood. These ranks of idle youth cannot contribute to nation building through their participation in economically productive activities (Chakraborty, 2014 [4]). Rather, the state has to take care of them through various material provisioning. They could be an asset for the country had they would attend schools to acquire skill. The state invests now for education for her children. The return would accrue during their productive youth. This universal quality schooling for all children in India is not only a legal obligation of the state but all economically beneficial action of the state. Child health is as important as child education. We need healthy youth for India's future growth. Full course child immunization for all children cannot be compromised. Physical incapacity in today's youths has a root in her neglected infancy. Crippled childhood beleaguered by ailments and deformities have a root in prenatal neglect of mothers. Good health of learners is primary condition for attaining learning competency. Attainments of skills that determine earning capacity of adults are contingent on 'healthy mind in a healthy body'.

Increasing economic inequality in growing India does not measure up with her global position as the largest democracy in the world. An average Chinese is three times richer that an average Indian despite china's accomplishment as more egalitarian state than what India is at this moment. Decomposition analysis of India's current state of inequality points out that rural income inequality causing this outcome. Economic divide in India has been reinforcing the social divide that mars India's rural society. Affluence of a few and destitution of many is pregnant with unwelcome possibilities of discord, violence and disruption. Foundation of the state of India is set to weaken. Persistent economic inequality in India evidently frustrates the avowed objective of inclusive growth enshrined in five year plan documents. The occurrence of economic inequality in India has followed definite pattern since her birth as free nation. It was very high in the fifties but fell later and continued to fall up to the end of seventies. Thereafter, from 1980, urban inequality went up but rural inequality did not. The latter grew in the new millennium. Opponents of the neoliberal economic policies complain of under-reporting of consumption or income data. One study reports that income of the super-rich grew by hooping 285 per cent between the periods from 1987 to 2000 . Wealth holdings of Indian billionaires stood at 23 per cent of GDP in 2008, up from only 0.8 per cent in 1996. Interstate difference in mean income and urban-rural gap of mean income within states are often held responsible for giving rise to India's current state of income inequality. Intrastate income inequality is no less responsible. Prosperous regions within each state of India offer better income opportunities that what backward and remote areas can do. Non-farm sector has been expanding rapidly and within that category service sector is expanding. Service sector works need skills in various trades. Thus unskilled and semi-skilled workers are left out in this new pattern. Formal employment is also characterized by duel wage structure. Wage differential is very high between skilled and unskilled workers. Even a full course of quality elementary education can make a difference in agricultural occupations. Skill in farm operation gained through training results in higher crop production and earnings. The study undertaken to assess the differential rate of return to education in contemporary India has revealed that graduate education makes a larger differences that primary education. Another kind of study to investigate the role of education in differential income finds that education of women brings in better family welfare through lower fertility, better child care and work participation. Attainment of skills for learners, however, does not hinge on mere school attendance. Schooling facilities in India have undergone spectacular expansion in recent years. Enrolment in elementary level of education in India has gone up manifold under the auspices of successive state interventions in recent years. Operation blackboard in the eighties was followed by DPEP, Sarva Shiksha Abhiyan and the right to free and compulsory education which is currently underway. Unfortunately a significant section of primary education completers has learnt very little. It appears that quality learning falls far behind qualitative expansion in elementary education. Research studies on the academic competency among India's school-going children have revealed shocking state of affairs with regard to quality attainment. Enrolment and attendance in schools does not automatically result in quality leanings and skill formations. Household poverty and caste disadvantages stand on the way to academic competency. Poor parents cannot afford supplementary tuition for their children. Poor quality of schooling is added by inadequate nutrition and deficient health care for a large segment of Indian children. They grow up as incapable and unskilled adults. Income disparity or earning differential has its roots embedded in education delivery system in particular and human capital formation in general. The state must create opportunities for growth for all through provisioning of universal quality education and healthcare

\section{Conclusions}

India's rising income inequality to large extent is caused by the enormous difference in learning outcomes after completion of education. While schools are almost accessible to all children, quality schooling is limited to the privileged few who only can afford it. Higher education institutions are being built up by private companies to seize the opportunity of growing demand for quality professional 
education. Some of the higher educational institutions run by the government as well as by private companies have been producing world class experts and professionals in the field of management, technology and medical sciences. But these institutions are few and far between. Admissions to this institution are highly exclusive. The rest of the public institutions are of varied standard. Private higher education institutions, mostly in the field of technical education, have been mushrooming in India since the period when the gate was opened for private investors. In the frantic effort to set up business through establishing and running private colleges, many of them are imparting low quality educations. The quality learning imparted to the learners in the higher education sector is skewed in favour of the reputed few. Income inequality in the emerging sector in the contemporary India's urban locations can be explained by this. The relationship between poverty and inequality as a subject has drawn attention of scholars of development studies particularly from the days of the end of colonialism. However, the link is certainly not straight forward as one would expect. They do not move in the same direction with equal intensity. Some poor countries are less unequal than the others. But no one can contradict that a rise in inequality would dampen the poverty reducing impact of an increase in per capita income. Some would opine that growth acceleration might not be possible without an increase in inequality. This trend exemplifies contemporary India where inequitable return to education has a hand in rising inequality in growing India. But the transitory inequality is less harmful than the structural inequality that characterizes Indian society for thousands of years. The state must set the goals of education and pursue the goals as priority agenda. The triple goals are universal access, equity and quality. Rising economic inequality can be stemmed by state action to achieve the goals. Those who cannot scale the ladder, on their own, to gain access to quality education must be pushed up by the state to have it.

\section{REFERENCES}

[1] Banerjee, A., and T. Piketty. 2003. "Top Indian Incomes: 1956-2000." World Bank Economic Review 19 (1): 1-20.

[2] Bhalla, S. 2002. "Imagine There's No Country: Poverty, Inequality and Growth in the Era of Globalization." Institute for International Economics, Washington, DC.
[3] Burra, N. 2008. "The Political Economy of Tribals in India in the Context of Poverty and Social Exclusion." Paper prepared for the India Poverty and Social Exclusion Report, New Delhi.

[4] Chakraborty, Sudip (2014), “An Enquiry in to Poverty and Human Wellbeing: An Indian Context”, Concept publishing Co .New Delhi

[5] Bourguignon, F., Ferreira, F.H.G. and Lustig, N.E. (eds) (2005) "The Microeconomics of Income Distribution Dynamics": World Bank, Washington, DCand Oxford University Press, New Delhi).

[6] Datt, G., and M. Ravallion. 2009. "Has Poverty in India Become Less Responsive to Economic Growth?" Background paper prepared for India Poverty Assessment Report, World Bank, Washington, DC.

[7] Dutta, P. V. 2006. "Returns to Education: New Evidence for India, 1983-1999." Education Economics 14 (4): 431-51.

[8] Janneke Pieters (2011),"Education and Household Inequality Change: A Decomposition Analysis for India," The Journal of Development Studies, 47:12,1909-1924,

[9] Kijima, Y. 2006. "Why Did Wage Inequality Increase? Evidence from Urban India 1983-99." Journal of Development Economics 81 (1): 97-117

[10] Pandey, P., S. Goyal, and V. Sundararaman. 2008. "Public Participation, Teacher Accountability, and School Outcomes." Policy Research Working Paper 4 777, World Bank, Washington, DC.

[11] Pratham. 2009. "ASER 2008-Annual Status of Education Report (Rural) 2008 (Provisional)." New Delhi: Pratham Resource Center.--. 2010. "ASER 2009-Annual Status of Education Report (Rural) 2009. Pratham Resource Center, New Delhi.

[12] NCERT (National Council of Educational Research and Training, India).2009. Learning Achievement of Children in Elementary Education: A Journey from Baseline to Midterm. New Delhi: NCERT.

[13] Sen Amartya (1999),: "Development as freedom", Oxford University Press, New Delhi

[14] Sundaram, K. 2007. "Employment and Poverty in India, 2000-2005." Economic and Political Weekly, July 28.

[15] Walton, M. 2008. Presentation to the Indian Planning Commission. --- 2010. "Inequality, Rents and the Long-Run Transformation of India." Unpublished manuscript, Kennedy School of Government, Harvard University, Cambridge, MA

[16] http://www-wds.worldbank.org Perspective on Poverty in India: Stylized Facts from Survey data, World Bank, 2011 